\title{
The Garuda Strikes Back: Indonesian Economic Diplomacy to Tackle European Union Protectionism on Crude Palm Oil
}

\section{Mohammad Ichlas El Qudsi, Indra Kusumawardhana, Volodymyr Kyrychenko}

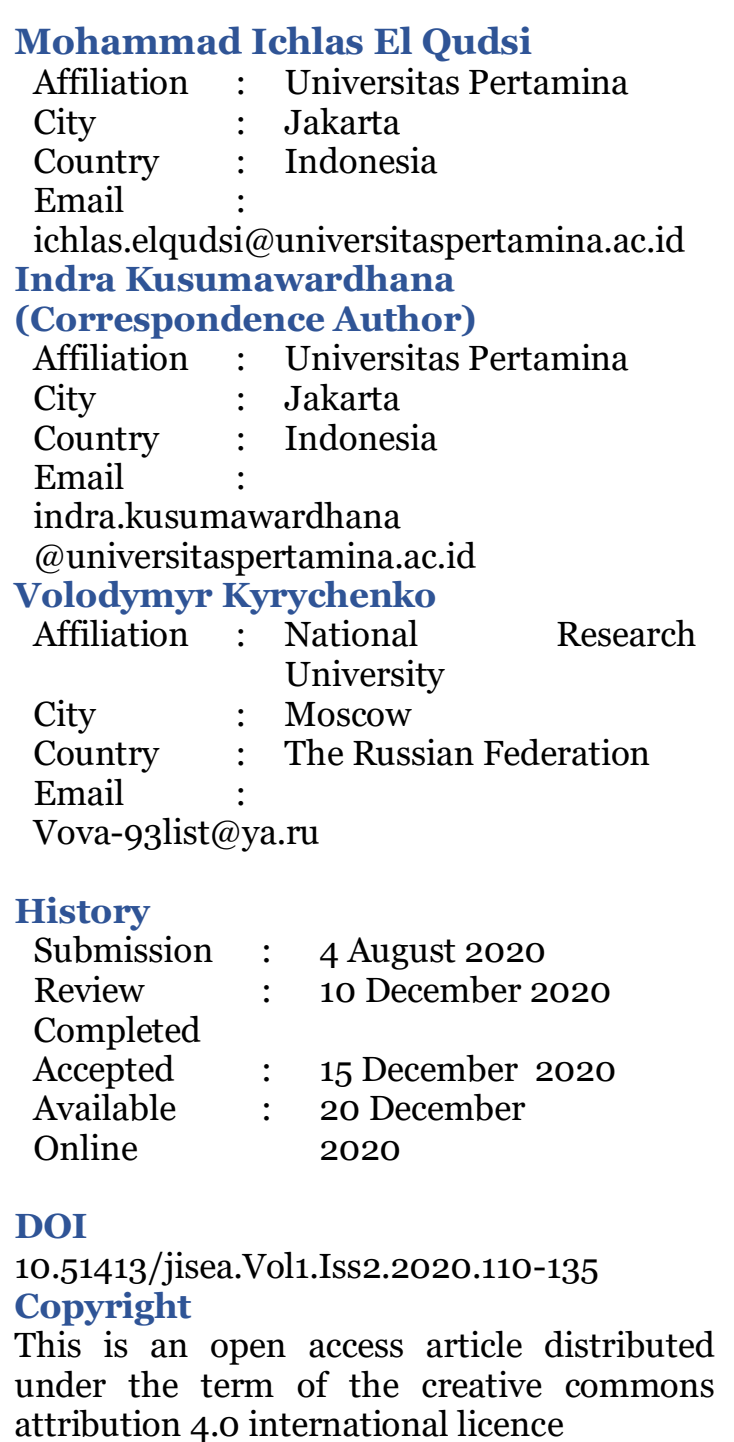

\begin{abstract}
This paper analyzes Indonesia's economic diplomacy in overcoming trade barriers to Indonesian palm oil commodities carried out by the European Union. Until now, the Indonesian Crude Palm Oil (CPO) industry has experienced tremendous pressure from the European Union (EU) as one of the main export destinations for Indonesian CPO. In order to secure Indonesia's national interests, instead of taking a cooperative approach, the Indonesian government has responded to the EU's discriminatory attitude towards palm oil commodities with a series of assertive economic diplomacy approaches. This assertive economic diplomacy approach is understood by this paper as a form of the "Power-Play End" strategy articulated by Indonesia to secure its national interests in mainland Europe. The main question in this paper is how can Indonesia use this strategy in overcoming trade barriers imposed by the EU on palm oil commodities? Using the concept of Economic Diplomacy which emphasizes three elements, namely the use of political influence and relations, the use of economic assets, the consolidation of the political climate and the international environment - this paper will examine Indonesia's economic diplomacy in related issues.
\end{abstract}

Key Words: Palm Oil, Economic Diplomacy, Trade Barriers, Indonesia, European Union

\section{Cite this article :}

Qudsi, M. I. El, Kusumawardhana, I., \& Kyrychenko, V. (2020). The Garuda Strikes Back: Indonesian Economic Diplomacy to Tackle European Union Protectionism on Crude Palm Oil. Journal of International Studies on Energy Affairs, 1(2), 110. https://doi.org/10.51413/jisea.Vol1.Iss2.2020.110135 


\section{INTRODUCTION}

The Indonesian Crude Palm Oil (CPO) industry is dealing with tremendous pressure from European Union discriminatory policy towards Crude Palm Oil (CPO). On January 2018, the European Parliament agreed by vote on its revision of the Renewable Energy Directive (RED) which now prohibits the use of crude palm oil (CPO) in the production of biodiesel for Europe (Wicaksono, 2018). The reasons for the ban include that conventional biodiesel does not contribute to greenhouse gas emissions due to the indirect impact of land use change (ILUC) from biofuels. According to European Commission, ILUC pertains to the When biofuels are produced on existing agricultural land, the demand for food and feed crops remains, and may lead to someone producing more food and feed somewhere else. This can imply land use change (by changing e.g. forest into agricultural land), which implies that a substantial amount of $\mathrm{CO}_{2}$ emissions is released into the atmosphere (Indirect Land Use Change (ILUC), 2012).

Indonesia government strongly against European Union (EU) decision to implement the Draft Delegated Regulation. Indonesia labelled the regulation as an outright discrimination and a disguised protectionist measure against palm oil (Indonesia: Europe Do Outright Discrimination Against CPO - The Insiders Stories, n.d.). Palm Oil is one of strategic leading export commodity for Indonesia, Indonesian exports achieved US $\$ 168.8$ billion in 2017 , a rise of $16.8 \%$ compared to the previous year (UN Comtrade 2018). Palm oil is one of the largest contributors to these number, amounting to $13.6 \%$ in 2017. Indonesian palm oil exports in 2017 reached US $\$ 22.97$ billion, an increase of $26 \%$ compared to the value in 2016, it makes Indonesia represents as the world's largest exporter of palm oil, surpassing Malaysia, Ecuador, Colombia and Thailand, with an export value of USD 4.2 billion in 2014 (UN Comtrade 2018; Gaol, 2018). On labor industry, based on data from the Ministry of Agriculture (2015), the number of employees working in oil palm plantation companies increased from 718 thousand people (2000) to 3.4 million people (2016). Thus, the number of 
workers absorbed directly is around 2 million people in 2000 increased to around 7.8 million in 2016. Smallholder farmers is about 40 percent of total production. On the other hand, there are dominant private enterprises (Wilmar Group and Sinar Mas Group) in producing slightly over half of total Indonesian palm oil output (Suwarno, 2017). In this context, Indonesia is very interested in ensuring that trade between Indonesia and the European Union remains based on free trade. Meanwhile, the ban on the use of palm oil in European industries on the pretext of damaging the environment has ignored the Indonesian palm oil industry's striving to comply with environmental ethics.

The dispute between European Union and Indonesia regarding Crude Palm Oil has been going on almost for a decade. After 2013, the European Union experienced a failure on allegations of dumping against Indonesia for bio-diesel products, thus imposing anti-dumping duties on Indonesian bio-diesel products by applying a dumping margin of $8.8 \%-23.3 \%$. Where the policy did not continue due to the decision of the Dispute Settlement Body (DSB) from the World Trade Organization (WTO), which stated that Indonesia was not proven to have implemented biodiesel dumping as alleged by the EU (WTO: Indonesia Tak Terbukti Terapkan Dumping Biodiesel | Gabungan Pengusaha Kelapa Sawit Indonesia (GAPKI), n.d.). Post this failure, the EU tried other approach to strengthen its pressure to discriminate against Indonesian CPO once more. In 2017 the European Parliament issued a resolution to prohibit the use of Biofuels produced from Palm Oil (Palm oil: EU ban won't save Asian rainforests, but here's what might help - Opinion - The Jakarta Post, n.d.). It does not stop there, in 2018, the EU Commission issued a draft regulation "Delegated Regulation Supplementing Directive 2018/2001 of the Europe Union (EU) Renewable Energy Directive II" or REDD II for short. Cleverly, this draft regulation will limit the effective use of palm-based Biodiesel in the EU through the use of the Indirect Land Use Change (ILUC) concept (Pemerintah akan kirim joint mission ke Eropa untuk menentang RED II, n.d.). Although this regulation 
One of the EU-28 policies, namely the Delegated Act on Low and High ILUC-Risk Biofuels tends to classify palm oil as "high risk-ILUC biofuel". Where the negative impact arising from the indirect conversion of forest land into land for biofuel / biodiesel feedstock is described by this regulation as a "sin" that arises because of the high demand for palm oil. This means that there will be more deforestation for the expansion of oil palm plantations in order to meet the raw material needs for the EU biodiesel market (Strategi Dampak Pemberlakuan Kebijakan RED II ILUC Uni Eropa - Majalah Sawit Indonesia, n.d.). Based on this paradigm, the EU wants to phase out the use of palm oil as a raw material for biodiesel by 2030 .

EU maneuvers that continue to put pressure on Indonesian CPO have made the Indonesian government have to face pressure from EU protectionism. In the context of this phenomenon, Dominick Salvatore in the book "A Model of Dumping and Protectionism in the United State" explains that protectionism is an economic policy of a country that limits trade between countries through trade systems, such as the imposition of import tariffs, quota restrictions, or in the form of a system of increasing tariffs and regulations, as well as various efforts to inhibit imports through pressures given to import destination countries and even import bans (Salvatore, 1989).

In its development, the EU efforts to implement protectionism at a practical level have found new ways apart from trade corridors, namely by using non-trade issues such as health, religion, labor protection and the environment. Protectionism efforts that articulate issues such as health, religion, labor protection and the environment make international trade increasingly intertwined with issues that previously appeared to have no correlation with trade (Aisbett \& Pearson, 2012). The EU's efforts to tackle palm oil as an important commodity in the processing of biofuels spans a wide variety of endeavors. There are at least two main issues that can be captured by this paper as a form of EU protectionism against Indonesian palm oil commodities, namely the accusation of Dumping which directly targets Indonesia's foreign policy 
in the context of international trade related to palm oil commodities, negative campaigns against palm oil targeting public perceptions in Indonesia. Mainland Europe towards the palm oil commodity, thus giving rise to various agreements codified in the regulations which became the regime in the European Region to prevent the entry of palm oil commodities there. It is at this point that Indonesia's Economic Diplomacy finds its challenges in being able to guard Indonesia's national interests in the trade of palm oil in the European market.

In this regard, this paper analyzes Indonesia's economic diplomacy efforts to overcome trade barriers for oil palm in the European Union. We tried to understand Economic Diplomacy through an IR lens, which is primarily concerned with high politics and national security issues, where national interests are mostly defined in terms of (inter)national stability (Bergeijk et al., 2011, p. 24). We did not use commercial diplomacy, because to the best of our knowledge, commercial diplomacy refers to activity by government service to the business community, which aims at the development of a socially profitable international business venture. This activity involved a commercial diplomat perform their main activities in the host country and usually staff members of a diplomatic mission or a trade promotion organization (TPO)/ investment promotion agency (Kostecki \& Naray, 2007). This article did not aim to analyze Indonesian diplomat dealing with trade issue; we want to focus on Indonesia's macro policy to tackle the European Union protectionism toward crude palm oil.

Meanwhile, according to Baine and Woolcock (2003:3), economic diplomacy as a set of activities (both regarding methods and processes for international decision making) related to cross-border economic activities (export, import, investment, lending, aid, migration) pursued by state and non-state actors in the real world. Since 2013 until today, Indonesia has been faced with the dynamics of growing problems related to the EU's efforts to block palm oil commodities' entry in 28 European countries. Rashid defines economic diplomacy as the process of formulating and negotiating policies related to production activities, 
exchange of goods, services, labour and investment in other countries (Killian, 2012). Odell offers a broader definition by including additional elements: the existence of policies related to the exchange of money and information, including foreign assistance or official development assistance (Odell, 2018). Based on those definitions, economic diplomacy is an essential element for a country in managing its economic relations with the outside world because international economic considerations do not occur in a vacuum that only relies on market forces as assumed by neoclassical economists. In this understanding, economic diplomacy then becomes an essential weapon for countries to cooperate or conflict in the international system.

In the context of Economic Diplomacy, Nicholas Bayne and Stephan Woolcock explained that the state government must be able to manage three interrelated pressures, namely: (1) Pressure caused by the interaction of political and economic dimensions; (2) Pressure caused by international and domestic dynamics; and (3) Pressure caused by interactions between the Government and other actors, such as companies or Non-Government Organizations (NGOs) (Bayne \& Woolcock, 2017). Based on this view, it can be understood that the state is not the only actor in economic diplomacy. The transformation of the global political economy has brought significant changes to various aspects of the life of the nation and state. Susan Strange is the first person to state that a new "diplomat" has been born in the global economic system, namely companies, which has created triangular diplomacy, namely diplomacy between countries and countries, companies and companies as well as countries and companies (Strange, 1991). In subsequent developments, the diplomacy process, especially economic diplomacy, is no longer triangular in nature, but rather a decagon or octagon involving far more actors such as NGOs and international organizations (Killian, 2012). 
At this point, the authors argue that the best approach is to understand the spectrum of problems faced by Indonesia through the definition of economic diplomacy which is in line with the realist school of thought, namely "Economic diplomacy has been defined as the pursuit of economic security within an anarchic system" (Lee \& Hocking, 2010). If the polemic that occurs at the international level is seen by the state as a threat in the economic dimension (Economic Security) which includes matters of economic welfare and political stability, the state will use an economic diplomacy approach that includes all available instruments, both economic and even political (Kopp, 2004). In that sense, the nation-state must understand that the achievement of national interests in the context of economic diplomacy must also recognize hard instruments aimed at increasing the state's bargaining on certain issues. Sometimes, cooperative steps are ineffective for solving some trade problem between two or more countries.

Countries in responding to challenges caused by global market dynamics require proper economic diplomacy. According to van Bergeijk and Moons, economic diplomacy contains three elements, namely: (a) Use of influence and political relations to promote and / or influence trade and investment, (b) Use of economic assets to increase costs of conflict and strengthen mutually beneficial relationships, (c) Efforts to consolidate the political climate and the international environment to achieve these goals (Bayne \& Woolcock, 2017: 3). These three elements are important references for analyzing Indonesia's economic diplomacy efforts in facing EU protectionism against palm oil commodities that have occurred until this writing. Therefore, the analysis carried out by this article will be divided into two parts - first, this paper will provide an overview of EU trade barriers to Indonesian palm oil commodities, then proceed with providing an analysis of Indonesia's economic diplomacy based on the three elements previously mentioned. Thus, this paper is expected to provide an explanation regarding Indonesia's economic diplomacy efforts in dealing with the current polemic. 


\section{THE EUROPEAN UNION AND TRADE BARRIERS TO PALM}

\section{OIL COMMODITIES}

Europe is a region whose countries are the largest consumers of vegetable oil in the world, both for food and non-food needs. However, in the European Union, palm oil is not the only vegetable oil consumed by the people of the blue continent. Apart from palm oil, there are three other vegetable oils that are also widely consumed by mainland European countries, namely soybean oil, rapeseed oil and sunflower oil. The European Union introduced the Bio-Fuel policy for the first time through The Directive on the promotion of the use of biofuels or other renewable fuels for transport (2003/30 / EC). Where the policy, known as RED, aims to mitigate the impact of energy use from fossil fuels which affects global climate change. In terms of numbers, this policy aims to increase the spread of biofuel use in the transportation sector by $2 \%$ in 2005 and $5.75 \%$ in 2010 . Because of this policy, the use of biofuels in the European Union has doubled between 2003 and 2005, although this figure was still below the 2\% target for biofuel use in 2005 . In that year the European Union could only reach $1.4 \%$ of the total use of biofuels (Amezaga, 2010).

Starting from there, in 2006, the European Union strengthened its commitment to the future use of biofuels by issuing the EU strategy for Biofuel document based on the Biomass Action Plan. This document provides a basis for the trajectory of biofuel use in EU countries through six strategies for biofuel development in the EU and developing countries. In this strategy document, the European Commission's political decision emphasizes the importance of meeting national targets for biofuel use and biofuel production using the use of sustainable raw materials (EUR-Lex - l28175 - EN - EUR-Lex, n.d.).

According to Timo Kaphengst, to fulfil the strategy document's objectives, the European Union was conducting a review of the policies to reposition and actualise policy directions in the region, emphasising the importance of sustainability in energy use in the European countries. 
Then, this policy was manifest through a Green Paper publication explaining the new European Union energy policy. This policy focuses on achieving three aspects: the first aspect is sustainability - the big goal pursued from this energy policy formulation is to reduce climate change by intensifying the use of renewable energy and efficient use of energy. The second aspect is competitiveness - this policy aims to increase efficiency and increase competitiveness through the competitive internal EU energy market. The third aspect is to talk about guaranteeing supply security, namely by establishing better coordination among EU member countries to fulfil energy supply in the European region (Schlegel \& Kaphengst, 2007). The European Union's grand strategy to encourage renewable energy was gaining reinforcement by the emergence of a renewable energy roadmap in 2007. This roadmap targets $20 \%$ renewable energy use for 2020 with a minimum of $10 \%$ biofuel use for the transportation sector, thus this roadmap changes the target in the 2003/30 directive. This regulation has also strengthened from previously voluntary to binding and mandatory for EU member states (Amezaga et al., 2010).

Interestingly, after the revision of the 2001/77 and 2003/30 renewable energy policies, it became a $2009 / 28$ directive - this policy contains propositions related to the biofuel industry chosen by the European Union to be developed towards second generation biofuels, namely biofuels originating from reserves and residue. agricultural products, with the aim of having no implications for the stability of food and world forests. The 2009/28 directive regulates several things, including: a target of $10 \%$ use of biofuel for transportation, a threshold for reducing the greenhouse gas effect estimated by 2017, the EU can reduce the greenhouse gas effect by $35 \%$ and regulates sustainability criteria (De Pous, 2009).

At this point, this paper sees that the regulations codified by the European Union in building environmental regimes in the European region are starting to have a connection with the palm oil commodity which is widely used by business lines in the blue continent. Where the 
criteria set by the European Commission regarding biofuel products must be produced from production activities that are environmentally friendly and sustainable, and do not affect forest stability. The definition of criteria related to sustainability is contained in article 17 which states that the biofuel produced must be able to reduce at least $35 \%$ of greenhouse gas emissions when compared to the use of fossil fuels. The article also regulates technically the biofuel used, starting from the raw material, the manufacturing process, to the amount of biodiesel produced can reduce the effect of greenhouse gases (Directive 2009/28/EC of The European Parliament and of The Council).

\section{INDONESIA'S ECONOMIC DIPLOMACY: THE THREE}

\section{STEPS TO STRIKE BACK!}

\section{Use of influence and political relations to promote and / or influence trade and investment}

To tackle European protectionism, Indonesia uses economic diplomacy to counter European black campaigns against palm oil by leveraging international political networks to promote the worldwide trade in palm oil. According to Hirchman (1985), economic diplomacy is clearly not just about narrow economic and commercial interests. Rather, it involves broad national interests that include political and strategic as well as economic dimensions. Indonesia's maneuvers to strengthen positive promotion of palm oil commodities around the world are a counter narrative to deny European efforts to label palm oil commodities as non-environmentally friendly commodities. Maintaining the image of the oil palm commodity is not just an economic problem, for Indonesia it is a very strategic national interest.

As an example, addressing the issues brought by the European Union in decreasing the use of palm oil, Indonesia issued a claim to reject this issue. Here are a few claims Indonesian government to deny the black campaign carried out by the European Union: 1 . The largest GHG (greenhouse gas) emissions globally are carbon dioxide gas which reaches $92 \%$ of total global GHG in 2011. 2. The largest sector in 
emitting $\mathrm{CO} 2$ is energy consumption / global fossil fuels, this sector contributes $56 \%$ of the total, while land development is $12.2 \%$. 3 . The largest biofuels emitter country in the world is China, United States, India, Russia, Japan, Germany, Iran, Canada, South Korea and United Kingdom. 4. Country The largest emitters of GHG from global agriculture are China, Brazil, India, United States, European Union and Argentina. 5. Deforestation occurs in countries that have non-tropical forests, Meanwhile, countries with tropical forests tend to experience reforestation (Repository UMY, n.d).

The Indonesian Ambassador to the European Union, Arif Havas Oegroseno, in a seminar on the European Union emphasized the importance of the Indonesian people to conduct research and promoting Indonesian palm oil on a global scene. This marked a culmination of Indonesia's dissatisfaction with the black campaign that became rampant even became advertisements in European television. Some foods even have a palm oil-free logo on the label the packaging. Furthermore, Riaz J. P. Saehu, an official at the Indonesian Embassy in Brussels considers protectionism carried out by EU countries as an act of jealousy over oil palm trees that difficult to grow on the plains of Europe while in Indonesia oil palm trees can thrive (Afrianti, 2014, p.13). For that he supported the existence of animated films that advertised support for palm oil. The film describes the fact that palm oil requires an area of 9 million hectares to make vegetable oil. This area is less compared to sunflower planting locations which require 12 million hectares of land. Nevertheless, many European countries have always relied on sunflower oil as bio-oil (Afrianti, Dewi, 2014).

Moreover, Indonesia also invited Malaysia to jointly fight for free trade related to palm oil. Obviously, economic diplomacy is thus part of-and at the same time an instrument of-foreign policy, concerned with decision-making processes and the employment of political-economic instruments (Bergeijk et al., 2011). Indonesia strengthens its positions against the European Union by fighting together with countries that are equally affected by EU protectionism on Palm Oil and its derivatives. 
Coordinating Minister for Economic Affairs Darmin Nasution said that Indonesia and Malaysia agreed to send their respective delegations to protest against the latest European Union regulations regarding palm oil. In the draft rules of the European Union's Delegation Act, palm oil will be banned from turning into biofuel by 2030 (RI dan Malaysia Layangkan Protes Soal Sawit ke Uni Eropa April - Bisnis Tempo.co, n.d.).

Indonesia also takes advantage of diplomatic relations to seek alternative markets besides the European Union. The export destination countries for Indonesian palm oil that experienced an increase in 2018 were China by $18 \%$, Bangladesh by $16 \%$, Pakistan $12 \%$, African countries by $13 \%$ and the United States by 3\% (Dijegal Uni Eropa, Kemdag berupaya perluas pasar ekspor minyak sawit, n.d.). For instance, during a current account deficit, the government and palm oil business actors work together to expand and strengthen the export market, one of which is by sending a trade mission delegation to Pakistan. Since 2014, Indonesian palm oil already dominated the Pakistani palm oil market. In 2014 Indonesia had a market share of 72.5\% which increased to 83\% in 2015 and 82\% in 2016 (Indonesia Kuasai 82\% Pasar Sawit di Pakistan - Ekonomi Bisnis.com, n.d.). This potential is used by Indonesia to overcome EU-EU protectionism by sending a delegation to Pakistan to strengthen the palm oil trade

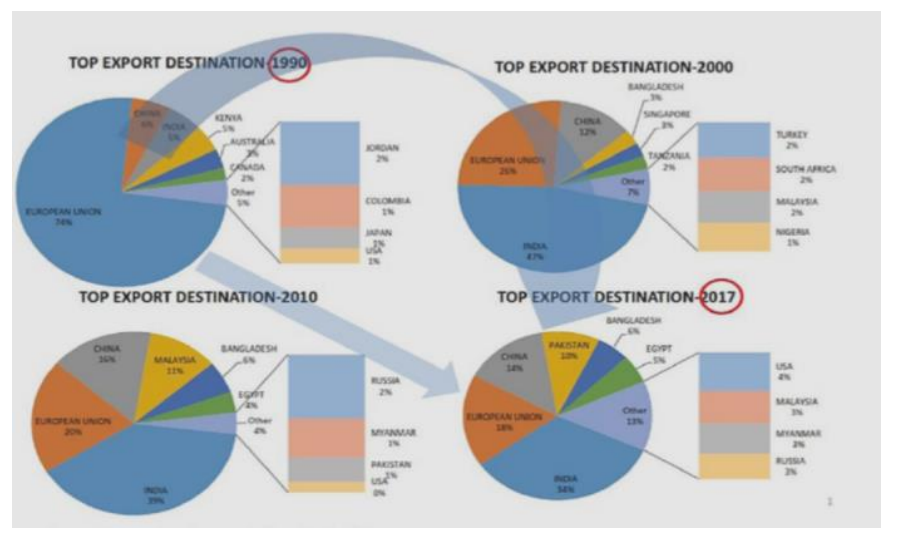

Figure.1 - Fundamental Shift Palm Oil Export 1990-2017 from EU to Asia Source: Observatorv Economic Comblexitv. MI in Suwarno. 2019. 
As illustrated in Figure 1, within 27 years, the Indonesian palm oil export destination experienced a pivotal shift from EU to Asia. Prior to 2000, Indonesian palm oil export significantly went to European Union, in number it accounted for $74 \%$. Whereas, the export to Asia is only about $11 \%$ which was to China and India. But, from 2000 a head, it was slightly decreasing export of Indonesian palm oil to EU that is about 26\%. In 2010, Export to EU was decreasing about $20 \%$ of Indonesian palm oil export. By then, in 2017, about 70\% of palm oil export went to Asia, and only a fraction of $18 \%$ went to EU. Indonesian palm oil export to India and African countries increased by 32 and 50 percent year-onyear, respectively and even exports to Europe increased by 15 percent from 4.37 million tons in 2016 to 5.03 million tons in 2017. Albeit increasing $15 \%$ of the Indonesian export to Europe, palm oil has been discriminated by the EU (Suwarno, 2017). Indonesia's policy maker also aware about the pivotal shifting in Indonesian palm oil export destination, Indonesia uses this advantage to weaken EU pressure on Indonesian palm oil commodities. Globally, Indonesia promotes openness for any country to buy Indonesian palm products. One of Indonesia's top prospectus destination is China, by anticipating a boost in exports of the commodity to China, the move also presents Indonesia with a respite from its own trade woes from a planned phase-out of palm oil from biofuel in the European Union, and a likely increase in duties by India, its No. 1 export customer (Jong, 2019). The deputy for energy in the office of the coordinating minister for the economy, mentioned that Indonesia was always looking to expand the market for its crude palm oil (CPO), including in China, it's third-largest market.

"We're the biggest CPO supplier. We can dictate the price. "That's the beauty of being the biggest supplier," Montty said. But boosting exports to China will not mean clearing more forests to plant oil palms. Instead, Indonesian producers will increase yields through better technology and seeds, rather than more acreage (Jong, 2019).

To the best of our knowledge, we agree that Economic diplomacy is a foreign policy practice and strategy that is based on the premise that 
economic/commercial interests and political interests reinforce one another and should thus be seen in tandem. Therefore, the way Indonesia exercised their political relations with countries that face the same threat as the protectionism of the European Union and countries outside Europe that need Palm Oil are not only to find a way out in facing European protectionism, but also a form of diplomatic message to the European Union that Indonesia can seek alternative market if Europe behaves unfairly in relation to palm oil trade.

\section{Use of economic assets to increase costs of conflict and strengthen mutually beneficial relationships}

This article argues that Indonesia is fighting back against European pressure on palm oil commodities. This argument is based on the following views, if economic security is thought to comprise the economic prosperity and political stability of a nation, it follows that economic diplomacy pursued by a government involves a variety of instruments that are relatively more economic or more political in character. In other words, economic diplomacy involves a 'business end' and a 'power-play end', and all tools (in mirror view: expressions) of economic diplomacy can be placed somewhere in between these two extremes (Bergeijk et al., 2011, p. 16). In a sense, Palm Oil as Indonesia's leading commodity is part of Indonesia's economic security, so that to overcome European Union protectionism, the pressure exerted by Europe will be countered by Indonesia by utilizing all available resources to push back. Luhut Binsar Panjaitan as Coordinating Maritime Affairs and Investment Minister stated that the Indonesian Government had considered implementing a boycott of European products (Upaya Ubah Diskriminasi Sawit Uni Eropa (UE) : Indonesia Jangan Gelap Mata | Gabungan Pengusaha Kelapa Sawit Indonesia (GAPKI), n.d.). To prove the seriousness of Indonesia, the Indonesian Energy and Mineral Resources Ministry introduced the nickel export ban to push local extractors to refine the ore domestically and export higher-value commodities. The ban will take effect in January 2020, two years earlier than previously planned. Using the 
2009 Law on Coal and Mineral Mining, which sought to prohibit the export of raw materials five years after the law took effect, Indonesia raises the nickel issue to the attention of all countries that need imports of crude nickel from Indonesia, including the European Union (Iswara, 2019).

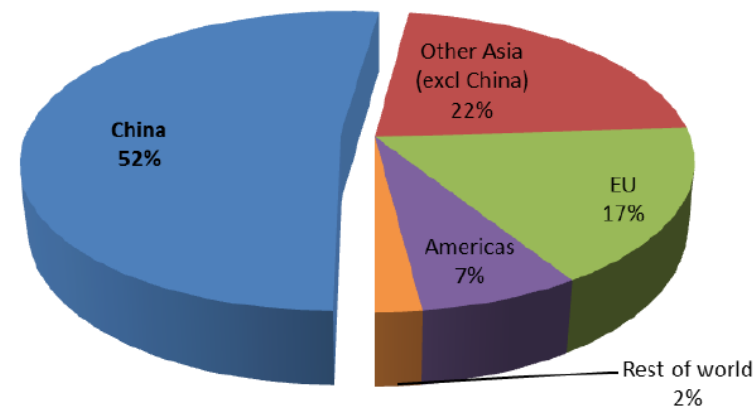

Figure 2 - Share of World Stainless Steel Production, by Region, 2014

Source: International Stainless-Steel Forum and INSG, Stainless Steel in Figures, 2015.

Responding to this trade policy of Indonesia, on November 2020, The European Union launched a complaint at the WTO against Indonesia's curbs on exporting nickel and other raw materials, which are designed to benefit its own smelting and stainless-steel industries (Blenkinsop, 2019). The European Union also sent a Request for Consultation to Indonesia's permanent representative for the WTO in Geneva.

My authorities have instructed me to request consultations with the Government of Indonesia pursuant to Articles 1 and 4 of the Understanding on Rules and Procedures Governing the Settlement of Disputes (DSU), Article XXII:1 of the General Agreement on Tariffs and Trade 1994 (GATT 1994) and Article 4.1 of the Agreement on Subsidies and Countervailing Measures (ASCM) with regard to various measures concerning certain raw materials necessary for the production of stainless steel, as well as a cross-sectoral import duty exemption scheme conditional upon the use of domestic over imported goods (UNION et al., 2019).

Nickel is a very important commodity for European Union countries. Data for 2014 (figure 1) shows that Europe represents 17\% of the world's largest stainless-steel producers. To support this market share figure, 
- JISEA Qudsi, Kusumawardhana, \& KyryChenko | The Garuda Strikes Back: Indonesian Economic Diplomacy to Tackle European Union Protectionism on Crude Palm Oil |

Europe really needs nickel imported from various countries, especially Indonesia. This need is proven by the number of world nickel imports in 2019, on which, most European countries are in the top 20 largest nickel importers in the world. Meanwhile, Indonesia has become the second-largest exporter of stainless steel and its share of the EU market has risen from near zero in 2017 to 18\% in 2019 (Blenkinsop, 2019). According to the European Commission, the restrictions unfairly limit access by EU producers to raw materials for steel production, notably nickel, as well as scrap, coal and coke, iron ore and chromium. Not surprisingly, the European Union responded to the Indonesian government's policy on nickel by bringing this issue as a case at the WTO. 


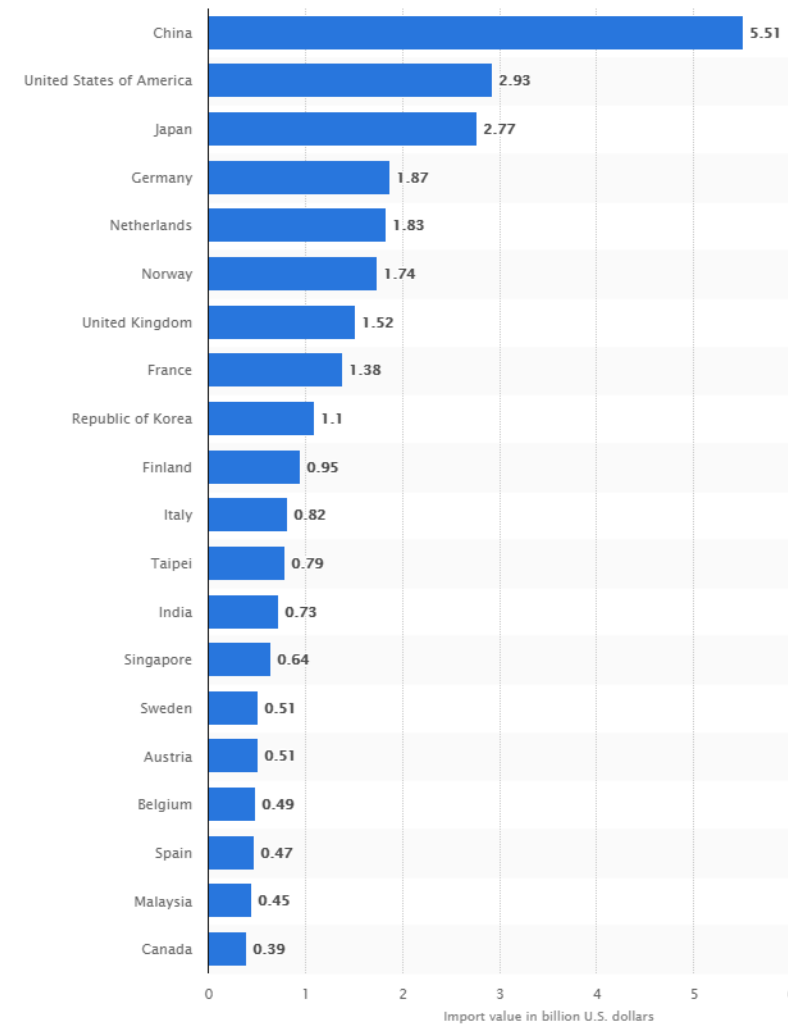

Figure 3 - The world's leading importers of nickel and nickel products in 2019, by country (in billion U.S. dollars)

Source: https://www.statista.com/statistics/1116992/global-nickel-imports-bycountry/

The Indonesian government is not surprised with the European Union's efforts to sue Indonesia in the WTO. In fact, it seems that Indonesia is waiting for the EU's response to the nickel issue. Indonesian Minister, Luhut Binsar Panjaitan statement, in November 2019, follows the filing of an EU lawsuit challenging Indonesia's nickel ore export ban through the World Trade Organization (WTO) stressed this "Don't ever [let] any country dictates Indonesian policy," (Iswara, 2019). Moreover, President Indonesia Joko Widodo reinforced this statement by stated, "We will face the suit at the WTO. Do not think that we will be nervous because of being sued," (Jokowi Says Ready to Deal With EU's Suit on Nickel Ban - News en.tempo.co, 2019). 
Based on Economic Diplomacy perspective, Economic diplomacy promotes economic interactions not only for their direct economic gains but also for the indirect benefits of stable political relations. An important element of economic diplomacy is the '[ $t$ ]he uses of economic assets and relationships to increase the cost of conflict and to strengthen the mutual benefits of cooperation and political stable relationships. By taking the same protectionist measures as the European Union, Indonesia seems to want to increase its bargaining capacity on the issue of palm oil which the European Union has been questioning for the past few years by EU tariffs on Indonesian palm oilbased biofuel- we could say Indonesia is striking back!.

\section{Efforts to consolidate the political climate and the international environment to achieve these goals}

The European Union is well known as the main retainer promoting free trade in the global economy but in recent years, it has increasingly adopted a curious double-standard. While adopting free trade within the bloc, the EU has been increasingly lobbied by big businesses to protect domestic industries while targeting competitive foreign industries from developing countries. One of the most egregious cases where this appears to be happening is in relation to palm oil for biofuels - recently classified by the European Commission as unsustainable, which means it cannot be counted toward EU renewable energy targets (How the European Union's protectionism is hurting developing economies, n.d.).

Using the REDD+ initiative, European Union attempted to hinder the CPO producing countries exporting activities into European market. The REDD+ initiative has been established at international level to combat deforestation and forest degradation in the tropics, where the vast majority of forest destruction takes place. REDD+ also has major implications for agriculture (the source of another $12 \%$ of global GHG emissions), rural development and adaptation to climate change in some of the most vulnerable parts of the world (Combatting tropical deforestation: the REDD+ initiative | Climate Action, n.d.). 
Unfortunately, the EU has not done enough to rein in its own direct role in such processes. For instance, the European Commission has long known that the biggest driver of deforestation is not palm oil from Asia, but beef and soy production from Latin America. It is also far from clear that the primary driver of deforestation in those countries is palm oil. For instance, in Indonesia, only 11 percent of deforestation could be attributed to palm oil plantations, compared to 27.4 percent due to tree plantations for pulp, forestry concessions and mining concessions (How the European Union's protectionism is hurting developing economies, n.d.).

Responding to this situation, two of the world's biggest palm oil producers, Indonesia and Malaysia - both multi-billion-dollar trading partners with the EU-condemned the policy and threatened trade retaliation. Indonesia filed a lawsuit with the WTO on December 15 after months of criticism of the EU's plan to impose tariffs on biodiesel made from palm oil. The EU's proposal is an attempt to stem deforestation and forest fires linked to the expansion of palm oil cultivation in Indonesia. This legal action also followed by the second largest palm oil producing countries, they will take legal action with the World Trade Organisation against the European Union's "anti-palm oil campaign" via a dispute settlement mechanism (Malaysia Follows Suit, Files Legal Action Against EU to WTO for Discriminating Against Palm Oil - The Palm Scribe, n.d.). Officials in both countries have shared that EU policies are restricting trade in palm oil, EU policies under its Delegation Regulation restricts free trade practices.

For instance, The Indonesian Deputy Minister of Trade expressed the view that "The European Union must be consistent with their rhetoric in terms of international trade. Oil palm discrimination clearly violates trade principles regulated in the WTO, " (Sambuaga, interview, 2020). Also, Malaysian Plantation Industries and Commodities Minister Mohd Khairuddin Aman Razali said the policies adopted by the EU in the Delegation Regulation under the European Union Renewable Energy 
Directive II have created unreasonable restrictions on Malaysia's sustainability efforts (Chu, 2020).

As mentioned before, Indonesia filed a lawsuit at the WTO following the plan of the European Union to gradually phase out the use of palm oilbased biofuels. The Indonesian government deems that the policy is discriminative and would negatively impact Indonesian exports of palm oil and biofuel to the regional grouping but also would tarnish the image of palm oil and its derivative products in the eyes of global trade. According to Woolcock (2002), ways to consolidate the correct political climate and international political economic environment to facilitate and institute these objectives involved trade diplomacy and covers multilateral negotiations. Therefore, it is the domain of the supranational organizations and institutions such as the World Trade Organization (WTO), the Organization for Economic Cooperation and Development (OECD) and the European Union (EU). Indonesian moved toward filled a lawsuit at the WTO was the first economic diplomacy act to consolidate the international environment view regarding Crude Palm Oil sector.

On July 2020, the WTO Dispute Settlement Body (DSB) has agreed to the second request of Indonesia to set up a panel examining the European Union's Palm Policies in biofuels. The panel will have six to nine months to issue its findings. The United States, Malaysia, Norway, Turkey, Singapore, Thailand, Russia, Japan, Korea, India, Honduras, Guatemala, Costa Rica, Colombia, China, Canada, Brazil and Argentina reserved their third-party rights to participate in the proceedings. This a great achievement from Indonesian economic diplomacy. Indonesia's first request was blocked at the DSB meeting on 29 June, but Indonesia did not falter with this rejection (WTO agrees to Indonesia palm dispute panel, n.d.). As the world's largest palm oil producer, Indonesia's interest to fight for Palm Oil as good commodity drive them to consistently maintains that Europe's Renewable Energy Directive (RED) II unfairly discriminates against the vegetable oil and is inconsistent with provisions in the WTO's goods, subsidies and 
technical barriers to trade agreements. Malaysia also backed the claim as RED II, which will effectively phase out palm oil from European biofuels by 2030 based on indirect land use change criteria, prohibits its use and restricts trade.

On 9 December 2019, Indonesia once more requested consultations with the European Union regarding certain measures imposed by the European Union and its member States concerning palm oil and oil palm crop-based biofuels from Indonesia. Indonesia claimed that the measures imposed by the European Union appear to be inconsistent with Articles 2.1, 2.2, 2.4, 2.5, 2.8, 2.9, 5.1.1, 5.1.2, 5.2, 5.6, 5.8, 12.1 and 12.3 of the TBT Agreement; and Articles I:1, III:4, X:3(a) and XI:1 of the GATT 1994. Also, Indonesia claimed that the measures imposed by the European Union member States appear to be inconsistent with: Articles 3.1(b) and 5 of the SCM Agreement; and Articles I:1 and III:2 of the GATT 1994 (WTO | dispute settlement - the disputes - DS593: European Union - Certain measures concerning palm oil and oil palm crop-based biofuels, n.d.). Responding to this consultation request, On 19 December 2019, Costa Rica and Guatemala requested to join the consultations. On 20 December 2019, Colombia requested to join the consultations. On 23 December 2019, Malaysia requested to join the consultations. On 24 December 2019, Argentina requested to join the consultations. On 26 December 2019, Thailand requested to join the consultations. Subsequently, the European Union informed the DSB that it had accepted the requests of Colombia, Costa Rica, Guatemala, Malaysia, and Thailand to join the consultations. The support of many countries from various regions for the request for consultation is proof that Indonesia's economic diplomacy. Indonesia has succeeded in fighting for fair trade related to palm oil through efforts to consolidate the international environment to pay attention to the inconsistency of the European Union towards free trade. 


\section{CONCLUSION}

Based on the analysis in this paper. We already discussed Indonesian economic diplomacy in dealing with EU protectionism in Bio-Fuel commodity, especially Crude Palm Oil. Indonesia exercised economic diplomacy to puts pressure on the European Union through three elements. Firstly, the use of influence and political relations to promote and/or influence trade and investment, Indonesia uses economic diplomacy to counter European black campaigns against palm oil by leveraging international political networks to encourage the worldwide trade in palm oil. We explained that economic diplomacy is a foreign policy practice and strategy lies on the premise that economic/commercial interests and political interests reinforce one another and should perceive in tandem. We illustrated this activity through the way Indonesia sent a diplomatic message to the European Union that Indonesia can seek alternative market if Europe behaves unfairly concerning palm oil trade and build a counter-narrative to promote palm oil. Secondly, Indonesia uses economic assets to increase costs of conflict and strengthen mutually beneficial relationships; they were fighting back against European pressure on palm oil commodities by exercising bans for nickel import as a strategic commodity for Europe. The pressure exerted by Europe countered by Indonesia by utilizing all available resources to push back. Lastly, to consolidate the political climate and the international environment to achieve these goals, Indonesia attempted to consolidate the international environment through WTO as a multilateral organization covering trade issues. Indonesia filed a lawsuit at the WTO following the European Union's plan to gradually phase out the use of palm oil-based biofuels. The Indonesian government deems that the policy is discriminative and would negatively impact Indonesian exports of palm oil and biofuel to the regional grouping and tarnish the image of palm oil and its derivative products in the eyes of global trade. Those strategic movements were essential for Indonesia in handling EU protectionism toward bio-fuel commodity. 


\section{REFERENCES}

A.O. Hirschman, National Power and the Structure of Foreign Trade, expanded edition (Los Angeles, CA: University of California Press, 1980, first published 1945); and D.A. Baldwin, Economic Statecraft (Princeton, NJ: Princeton University Press, 1985).

Bergeijk, P. A. G. van, Okano-Heijmans, M., \& Melissen, J. (2011). Economic Diplomacy. In Diplomatic History (Vol. 22, Issue 1). https://doi.org/10.1111/1467-7709.00107

Blenkinsop, P. (2019). EU takes Indonesia to WTO over nickel ore export curbs | Reuters. https://br.reuters.com/article/us-euindonesia-trade/eu-takes-indonesia-to-wto-over-nickel-oreexport-curbs-idUSKBN1XW1D8

$\mathrm{Chu}, \mathrm{M}$. mei. (2020). Malaysia to file WTO legal action against EU over restrictions on palm biofuel - Business - The Jakarta Post. The Jakarta Post.

https://www.thejakartapost.com/news/2020/07/02/malaysia-tofile-wto-legal-action-against-eu-over-restrictions-on-palmbiofuel.html

Combatting tropical deforestation: the REDD+ initiative | Climate Action. (n.d.). Retrieved December 28, 2020, from https://ec.europa.eu/clima/policies/forests/deforestation_en

Dijegal Uni Eropa, Kemdag berupaya perluas pasar ekspor minyak sawit. (n.d.). Retrieved December 17, 2020, from https://nasional.kontan.co.id/news/dijegal-uni-eropa-kemdagberupaya-perluas-pasar-ekspor-minyak-sawit

EUR-Lex - l28175 - EN - EUR-Lex. (n.d.). Retrieved December 13, 2020, from https://eur-lex.europa.eu/legalcontent/EN/TXT/?uri=LEGISSUM\%3Al28175

How the European Union's protectionism is hurting developing economies. (n.d.). Retrieved December 28, 2020, from https://www.trtworld.com/opinion/how-the-european-union-sprotectionism-is-hurting-developing-economies-26771

Indirect Land Use Change (ILUC). (2012, October 17). https://ec.europa.eu/commission/presscorner/detail/en/MEMO _12_787 
Indonesia: Europe Do Outright Discrimination Against CPO - The Insiders Stories. (n.d.). Retrieved January 21, 2021, from https://theinsiderstories.com/indonesia-europe-do-outrightdiscrimination-against-cpo/

Indonesia Kuasai 82\% Pasar Sawit di Pakistan - Ekonomi

Bisnis.com. (n.d.). Retrieved December 17, 2020, from https://ekonomi.bisnis.com/read/20170126/12/623082/indonesi a-kuasai-82-pasar-sawit-di-pakistan

Iswara, M. A. (2019). Luhut defends nickel export ban amid EU complaints - Business - The Jakarta Post. Jakarta Post. https://www.thejakartapost.com/news/2019/12/18/luhutdefends-nickel-export-ban-amid-eu-complaints.html

Jokowi Says Ready to Deal With EU's Suit on Nickel Ban - News en.tempo.co. (2019). Tempo.

https://en.tempo.co/read/1282937/jokowi-says-ready-to-dealwith-eus-suit-on-nickel-ban

Jong, H. (2019). Indonesia eyes palm oil export boost to China amid mounting U.S. trade war. Mongabay.

https://news.mongabay.com/2019/o8/indonesia-eyes-palm-oilexport-boost-to-china-amid-mounting-u-s-trade-war/

Malaysia Follows Suit, Files Legal Action Against EU to WTO for Discriminating Against Palm Oil - The Palm Scribe. (n.d.).

Retrieved December 28, 2020, from https://thepalmscribe.id/malaysia-follows-suit-files-legal-actionagainst-eu-to-wto-for-discriminating-against-palm-oil/

Palm oil: EU ban won't save Asian rainforests, but here's what might help - Opinion - The Jakarta Post. (n.d.). Retrieved December 13, 2020, from

https://www.thejakartapost.com/academia/2019/05/o7/palmoil-eu-ban-wont-save-asian-rainforests-but-heres-what-mighthelp.html

Pemerintah akan kirim joint mission ke Eropa untuk menentang RED II. (n.d.). Retrieved December 13, 2020, from https://nasional.kontan.co.id/news/pemerintah-akan-kirim-jointmission-ke-eropa-untuk-menentang-red-ii

Repository UMY, n.d, FACTS AND CAUSES OF EU DECISION TO 
STOP PALM OIL IMPORT,

http://repository.umy.ac.id/bitstream/handle/123456789/28172/

7.\%20Bab\%20III_1.pdf? sequence $=7$ \&isAllowed $=\mathrm{y}$

RI dan Malaysia Layangkan Protes Soal Sawit ke Uni Eropa April -

Bisnis Tempo.co. (n.d.). Retrieved December 13, 2020, from

https://bisnis.tempo.co/read/1186641/ri-dan-malaysia-

layangkan-protes-soal-sawit-ke-uni-eropa-april/full\&view=ok

Strategi Dampak Pemberlakuan Kebijakan RED II ILUC Uni Eropa -

Majalah Sawit Indonesia. (n.d.). Retrieved December 13, 2020,

from https://sawitindonesia.com/strategi-dampak-

pemberlakuan-kebijakan-red-ii-iluc-uni-eropa/

Suwarno, W. (2017). The Challenge of Indonesian Diplomacy Against

Palm Oil Discrimination. Jurnal Ilmiah Hubungan Internasional, 15(2), 197-212.

UNION, E., Mission, P., \& Organization, to the W. T. (2019). Request for Consultations by the European Union.

Upaya Ubah Diskriminasi Sawit Uni Eropa (UE) : Indonesia Jangan

Gelap Mata | Gabungan Pengusaha Kelapa Sawit Indonesia

(GAPKI). (n.d.). Retrieved December 17, 2020, from

https://gapki.id/news/14684/upaya-ubah-diskriminasi-sawit-

uni-eropa-ue-indonesia-jangan-gelap-mata

Wicaksono. (2018). The reasons the European Parliament agrees to stop using CPO for its biodiesel - The Palm Scribe.

Thepalmscribe.Id. https://thepalmscribe.id/2018-1-24-thereasons-the-european-parliament-agrees-to-stop-using-cpo-forits-biodiesel/

WTO : Indonesia Tak Terbukti Terapkan Dumping Biodiesel |

Gabungan Pengusaha Kelapa Sawit Indonesia (GAPKI). (n.d.).

Retrieved December 13, 2020, from

https://gapki.id/news/4415/wto-indonesia-tak-terbukti-terapkandumping-biodiesel

WTO | dispute settlement - the disputes - DS593: European Union Certain measures concerning palm oil and oil palm crop-based biofuels. (n.d.). Retrieved December 28, 2020, from https://www.wto.org/english/tratop_e/dispu_e/cases_e/ds593_ e.htm 
- ISEA Qudsi, Kusumawardhana, \& KyryChenko | The Garuda Strikes Back: Indonesian Economic Diplomacy to Tackle European Union Protectionism on Crude Palm Oil |

WTO agrees to Indonesia palm dispute panel. (n.d.). Retrieved December 28, 2020, from https://www.argusmedia.com/en/news/2129123-wto-agrees-toindonesia-palm-dispute-panel 